$\square$

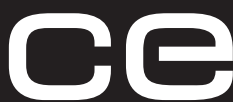

Institution of Civil Engineers

publishing

\title{
Award-winning paper in 2016
}

Papers published in Magazine of Concrete Research are eligible for awards from the Institution of Civil Engineers. Papers from any of the ICE journals can be nominated for several awards. In addition, each journal has awards dedicated to their specific subject area.

On Friday 6 October 2017, ICE president Tim Broyd presented an award to the following paper published in Magazine of Concrete Research in 2016. The Editorial Panel nominated their best papers and an awards committee chaired by Nigel Wright allocated the awards.

\section{Magazine of Concrete Research Prize}

The Magazine of Concrete Research Prize, awarded for the best paper published in Magazine of Concrete Research, was awarded to Lye et al. (2016).

\section{Abstract}

This study presents an analysis of a 30000 strong data matrix derived from 227 studies originating from 35 countries since 1968 . Similar to the fly ash effect, the carbonation of concrete increases with the incorporation of ground granulated blast-furnace slag (GGBS), but the rate increases as GGBS content is increased. This effect is greater for concrete designed on an equal water/cement (w/C) basis to the corresponding Portland cement (PC) concrete than on an equal strength basis. The Eurocode 2 specification for XC3 carbonation exposure in terms of the characteristic cube strength of concrete (or its $\mathrm{w} / \mathrm{c}$ ratio) may need to be increased (or decreased) with the addition of GGBS. Other influencing factors, including GGBS fineness, total cement content and curing, were also investigated. In some cases, the carbonation of in-service GGBS concrete has been estimated to exceed the specified cover before 50 years of service life. Measures to minimise the carbonation of GGBS concrete are proposed. Fully carbonated reinforced GGBS concrete is assessed to show a higher corrosion rate. In relation to PC concrete, the carbonation of GGBS concrete is essentially similar when exposed to $3-5 \%$ carbon dioxide accelerated or indoor natural exposure, and the conversion factor of 1 week accelerated carbonation equal to 0.6 year is established.

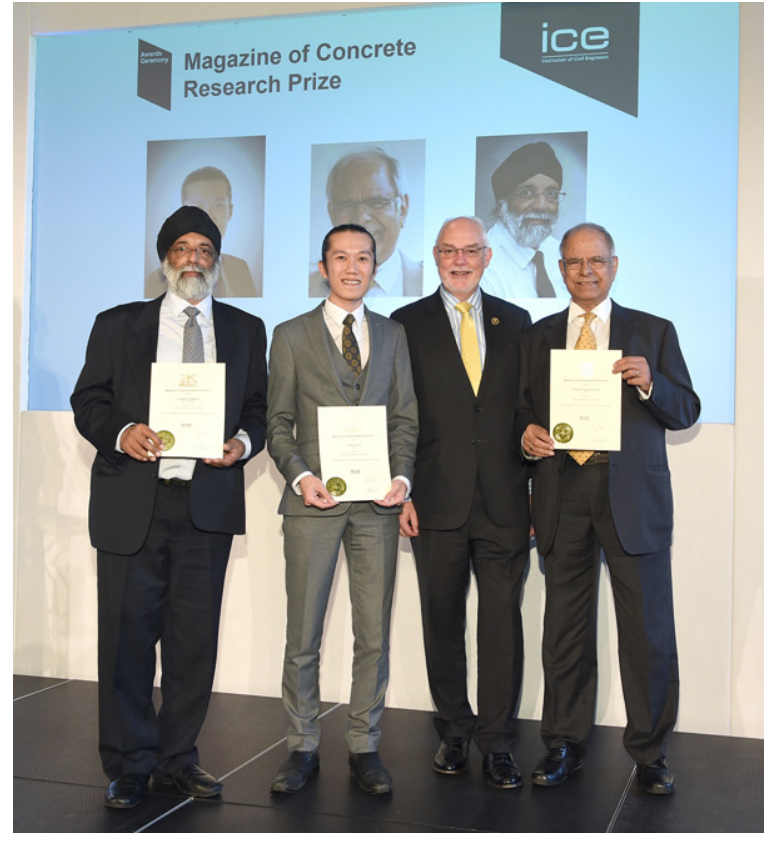

Gurmel S. Ghataora, Chao-Qun Lye and Ravindra K. Dhir, winners of the Magazine of Concrete Research Prize, with ICE president, Tim Broyd

\section{REFERENCE}

Lye CQ, Dhir RK and Ghataora GS (2016) Carbonation resistance of GGBS concrete. Magazine of Concrete Research 68(18): 936-969, https://doi.org/10.1680/jmacr.15.00449. 